\title{
Effect of crude fibre, feeding level and body weight on apparent digestibility of compound feeds by swine
}

H. Everts, B. Smits and A. W. Jongbloed (Institute for Livestock Feeding and Nutrition Research (IVVO), P.O. Box 160, 8200 AD Lelystad, Netherlands)

Received 15 July 1986; accepted 8 September 1986

\begin{abstract}
The effect of crude fibre content of the feed, feeding level, body weight and method of measuring on apparent digestibility of dry matter $(\mathrm{T})$, organic matter (O) and crude protein (XP) was investigated in growing pigs and adult sows. Most factors influenced digestibility significantly.

Key words: swine, digestibility, feeding level, body weight, crude fibre.
\end{abstract}

Introduction. The digestibility of feeds can be influenced by several factors such as chemical composition of the diet, the measuring technique, the feeding level and the body weight or age of the animals. However in some cases it is rather difficult to estimate the effect of a single factor. The effect of crude fibre content, for example, can be confounded with an increased dry matter intake if equal energy intake is aimed at. Furthermore the effect of body weight or age is often measured at different levels of feed intake, especially when growing pigs are compared with adult sows. In this experiment several factors were studied.

Material and methods. Twenty two adult sows (liveweight $185-220 \mathrm{~kg}$ ) and 18 growing male pigs (liveweight $35-105 \mathrm{~kg}$ ) were used for measuring apparent digestibility $(d)$ of $\mathrm{T}, \mathrm{O}$ and XP using the classical method of total faeces collection (during 10 days) or the $\mathrm{Cr}_{2} \mathrm{O}_{3}$ indicator method (during limited periods for 5 successive days). Three compound feeds with 43,76 or $113 \mathrm{~g}$ XF per $\mathrm{kg}$ T contained almost equal concentrations of net energy for fattening $\left(\mathrm{NE}_{\mathrm{f}}\right)$ and digestible protein. This was obtained by substituting maize starch for wheat middlings, lucerne meal (16-18\% XP), citrus pulp (dried), renderer fat and potato protein (dried). Feeding levels of $1.2,2.4$ and 3.6 times maintenance $\left(\mathrm{M}=293 \mathrm{~kJ} \mathrm{NE}_{\mathrm{f}}\right.$ per $\left.\mathrm{kg}^{0.75}\right)$ were used. The 3.6 $\times \mathrm{M}$ level was only fed to lactating sows; the other levels were fed to empty or early pregnant sows and to growing pigs. All animals were fed twice a day. Sows received feed in a dry form and growing pigs as slurry. This feeding method was thought not to effect digestibility.

The sows were tethered or kept in metabolism cages and the growing pigs were kept in pens or in metabolism cages. Not all possible combinations of feed, feeding level, housing and methods of measuring digestibility were investigated.

Results. In sows and growing pigs the three feeds differed significantly in $d_{\mathrm{T}}, d_{\mathrm{O}}$ and $d_{\mathrm{XP}}$. An increase of XF in dry matter with 1 percentage unit decreased $d_{\mathrm{O}}$ by 1.8 
units in sows and 2.3 units in growing pigs. For $d_{\mathrm{XP}}$ the decrease in sows was 1.1 units and in growing pigs 1.4 units. These figures are about the same as shown by Norfeldt et al. (1954). An increase in feeding level from $1.2 \times \mathrm{M}$ to $2.4 \times \mathrm{M}$ decreased - irrespective the feed - digestibility significantly in growing pigs $\left(d_{\mathrm{T}}-1.7\right.$; $\left.d_{\mathrm{O}}-1.8 ; d_{\mathrm{XP}}-3.4\right)$.

In sows an increase in feeding level from $1.2 \times \mathrm{M}$ to $2.4 \times \mathrm{M}$ resulted in a significant decrease of $d_{\mathrm{T}}, d_{\mathrm{O}}$ and $d_{\mathrm{XP}}$ of $-2.8,-2.8$ and -5.4 respectively. An increase from $1.2 \times \mathrm{M}$ to $3.6 \times \mathrm{M}$ resulted in a significant decrease of $d_{\mathrm{T}}, d_{\mathrm{O}}$ and $d_{\mathrm{XP}}$ of -3.1 , -3.4 and -6.5 respectively. This indicated a non-linear effect of feeding level on digestibility. An effect of feeding level was also shown by Parker \& Clawson (1967) and Cunningham et al. (1962), but not by Nehring et al. (1960) and Dammers (1964).

In growing pigs digestibility increased with body weight: for $d_{\mathrm{T}}, d_{\mathrm{O}}$ and $d_{\mathrm{XP}}$ with $0.56,0.46$ and 1.04 units respectively per $10 \mathrm{~kg}$ increase in body weight. Comparison between growing pigs $(70 \mathrm{~kg})$ and adult sows at a feeding level of $1.2 \times \mathrm{M}$ showed in general no higher digestibility of the three feeds in sows. Norfeldt et al. (1954) and Fernandez et al. (1979) showed higher digestibilities in pigs with a body weight of $180 \mathrm{~kg}$ or more. Differences in feeding level cannot be excluded as a confounding factor in their experiments.

The $\mathrm{Cr}_{2} \mathrm{O}_{3}$ indicator method showed a lower digestibility of about 1 unit and a smaller standard deviation for $d_{\mathrm{T}}$ and $d_{\mathrm{O}}$ than the classical collection method. Parker \& Clawson (1974) and Petry \& Enders (1974) observed the same tendency.

Conclusions. The crude fibre content of the feed and the feeding level reduced $d_{\mathrm{T}}$, $d_{\mathrm{O}}$ and $d_{\mathrm{XP}}$ significantly in growing pigs and adult sows. The effect of feeding level in sows was not linear. Feeding level and probably the XF content of the feed can affect the rate of passage of digesta through the gastrointestinal tract. A higher rate of passage can decrease digestibility by a lesser degree of fermentation in the hind gut (van Es, 1982). In growing pigs $d_{\mathrm{T}}, d_{\mathrm{O}}$ and $d_{\mathrm{XP}}$ was influenced by body weight, but a comparison between growing pigs $(70 \mathrm{~kg})$ and adult sows fed at the same feeding level showed no significant differences. Total faeces collection tended to give a higher digestibility than the $\mathrm{Cr}_{2} \mathrm{O}_{3}$ indicator method.

\section{References}

Cunningham, H. M. , D. W. Friend \& J. W. G. Nickolson, 1962. The effect of age, body weight, feed intake and adaptability of pigs on the digestibility and nutritive value of cellulose. Canadian Journal of Animal Science 42: 167-175.

Dammers, J., 1964. Verteringsstudies bij het varken. Thesis, University of Leuven. Published by IVVO, Lelystad.

Es, A. J. H. van, 1982. Energy metabolism in pigs: a review. In: N. Ekern \& F. Sundstøl (Eds.), Energy metabolism of farm animals (Proceedings of the 9th Symposium, Lillehammer), p. 249-255. Agricultural University of Norway, Aas.

Fernandez, J. A., A. Just \& H. Jorgensen, 1979. Comparison of the ability of growing pigs and sows to digest different feedstuffs. 30th Annual Meeting of EAAP, Harrogate, England, 23-26 July, Paper P 5.7 . 
Nehring, K., R. Schiemann, L. Hoffmann \& W. Klippel, 1960. Die Verwertung der Futterenergie in Abhängigkeit von Ernährungsniveau. Versuche mit Schweinen. Archiv für Tierernährung 10: 275320.

Norfeldt, S., A. Ruudvere, E. Toiger \& P. Lagerwall, 1954. Digestibility experiments with pigs. Kungliga Lantbrukshögkolans Annaler 21: 1-29.

Parker, J. W. \& A. J. Clawson, 1967. Influence of level of total feed intake on digestibility, rate of passage and energetic efficiency of reproduction in swine. Journal of Animal Science 26: 485-489.

Petry, H. \& H. Enders, 1974. Kritische Betrachtungen über die Zuverlassigkeit der im klassischen Verdauungsversuch und nach der Chromoxid-Indikatormethode bestimmten Verdauungskoeffizienten. Zeitschrift für Tierphysiologie, Tierernährung und Futtermittelkunde 33: 88-98.

This synopsis is based on a report by G. Oude Elferink, A. Mentink, H. Everts, B. Smits \& $A$. W. Jongbloed, entitled 'Digestibility in swine depending on several factors: literature research and report of a number of trials', Report IVVO No 174, Institute for Livestock Feeding and Nutrition Research, Lelystad, 1986. 81 pp., 10 figs., 39 tables, 79 refs., 6 appendices.

Available as paper copy (order R060P, $f 20$ including postage) or microfiche (order R060M, $f 12.50$ including postage) at: NARD, clo Pudoc, P.O. Box 4, 6700 AA Wageningen, Netherlands (telex 45015 blhwg nl).

\title{
Influence of potassium fertilizer on yield of upland kangkong (Ipomoea aquatica Forsk.)
}

A. R. Linnemann, S. Hitipeuw, B. Kruiger and E. Westphal (Department of Tropical Crop Science, Agricultural University, P.O. Box 341, 6700 AH Wageningen, Netherlands)

Received 4 September 1986; accepted 24 September 1986

\begin{abstract}
In a greenhouse experiment, effects of potassium fertilization on yield and potassium content of kangkong (Ipomoea aquatica Forsk.) were investigated. Kangkong was either ratooned (ratoon method) or resown after harvesting whole plants (seed method).
\end{abstract}

Key words: kangkong, Ipomoea aquatica, leaf vegetable, potassium fertilization, yield, ratoon method.

Introduction. Kangkong, a popular leaf vegetable in Southeast Asia, has received little research attention. Information on effects of cultural practices, among which manuring, on quality and yield of kangkong is limited (Cornelis et al., 1985). In a 